\title{
Data Port
}

National Cancer Institute

\section{Source}

National Cancer Institute. Data Port. NCI Thesaurus. Code C63634.

An connective access point for telecommunication devices, such as modems or fax

machines, for the transmission of data. 